NBER WORKING PAPER SERIES

\title{
SAVING AND COHABITATION: THE ECONOMIC CONSEQUENCES OF LIVING WITH ONE'S PARENTS IN ITALY AND THE NETHERLANDS
}

\author{
Rob Alessie \\ Agar Brugiavini \\ Guglielmo Weber \\ Working Paper 11079 \\ http://www.nber.org/papers/w11079 \\ NATIONAL BUREAU OF ECONOMIC RESEARCH \\ 1050 Massachusetts Avenue \\ Cambridge, MA 02138 \\ January 2005
}

Paper presented at the NBER 2004 International Seminar On Macroeconomics, Reykjavik, Iceland. We are grateful for helpful discussions with Gianpiero Dalla Zuanna, Ra.aele Miniaci and Antonio Nicolò and for comments by our discussants, Mihir Desai and Michael McMahon, and by the conference audience.Work supported in part by the European Union under contracts HPRN-CT-2002-00235 (Economics of Aging in Europe - AGE) and QLK6-CT-2002-002426 (Advanced Multidisciplinary Analysis of New Data on Ageing - AMANDA). The second and third author also acknowledge financial support from the Italian Ministry of Education, Universities and Research (MIUR). This study is based on the Social Economic Panel (SEP) survey administrated by Statistics Netherlands. The views expressed in this study are of the authors and do not necessarily reflect the views of Statistics Netherlands. The views expressed herein are those of the author(s) and do not necessarily reflect the views of the National Bureau of Economic Research.

(C) 2005 by Rob Alessie, Agar Brugiavini, and Guglielmo Weber. All rights reserved. Short sections of text, not to exceed two paragraphs, may be quoted without explicit permission provided that full credit, including (C) notice, is given to the source. 
Saving and Cohabitation: The Economic Consequences of Living with One's Parents in Italy and the Netherlands

Rob Alessie, Agar Brugiavini, and Guglielmo Weber

NBER Working Paper No. 11079

January 2005

JEL No. E2, D1, D9, J1

\begin{abstract}
The paper deals with the e.ects of cohabitation of grown children with their parents on household saving, using data from Italy and the Netherlands. It presents a two-period gametheoretical model where the child has to decide whether to move out of the parental home. This decision is affected by transaction costs, the child's preference for independence, and by the consumption loss induced by the move (consumption is a public good while the child lives in the parental home). We show that the child's income share affects the household saving decision, in contrast with predictions of the standard unitary model of household decision making. Empirical results from both countries are supportive of the key model predictions. We find strong positive effects of the child income share on the saving rate in Italy, where we calculate saving as the di.erence between disposable income and consumption but cannot distinguish children who will leave from those who will stay. We also find some significant effects of the child income share on household saving rate in the Netherlands, where saving is computed as the change over time in financial wealth. In the Dutch data we distinguish between children who stay and children who leave. The effect of the child's income share is significantly negative for those who stay, positive for those who leave.
\end{abstract}

$\begin{array}{lll}\text { Rob Alessie } & \text { Agar Brugiavini } & \text { Guglielmo Weber } \\ \text { Utrecht University } & \text { Universita Ca Foscari di } & \text { Universita di Padova } \\ \text { Vredenburg } 138 & \text { Venezia } & \text { Via del Santo 33 } \\ \text { 3511 BG Utrecht } & \text { San Giobbe } 873 & \text { I-35123 Padova } \\ \text { The Netherlands } & \text { I-30121 Venezia } & \text { guglielmo.weber@unipd.it }\end{array}$




\section{Introduction}

Much economic theory on saving takes the nuclear household as the benchmark for its analysis. The standard assumption is that children leave home as soon as they are of age, and that they become independent consumption units as soon as they do so.

Yet, we have evidence of wide-spread cohabitation of at least two generations in some European countries, as well as in some Far Eastern countries. In these European countries the common pattern is not so much for the elderly to live with their children, rather for grown children to leave home well after they become of age. We define those households where grown children live with their parents as "composite households". We provide evidence from Italian survey data that composite households differ in their saving behavior: for all ages over 50, composite households' saving rates are higher than nuclear households' saving rates. One possible implication is that countries characterized by higher cohabitation have higher aggregate household saving.

The economic issue we investigate is the link between cohabitation and saving. But this calls into questions the reasons behind cohabitation, a topic that has been investigated in a number of papers, that point to imperfections in either the labour market or in the credit market (possibly in conjunction with the housing market). For instance, Fogli [14] and Becker et al. [6] stress the importance of lack of job security for the young in delaying the time of independence, while Guiso and Jappelli [15] stress that rent controls and severe imperfections in the mortgage market make it hard for young Italians to move out of the parental home. However, recent work by Manacorda and Moretti [18] suggests that parental preference for living with their children may play a major role in explaining cohabitation, to the point that parents would choose to work harder to offer their grown children a higher standard of living if they remain in the parental home.

In this paper we show how differences in saving rates found in micro data can shed light on the presence and nature of these imperfections or differences in preferences across generations. In particular, we want to assess the role played by transaction costs in the housing markets. If such costs are particularly high for both trading down (by the parents) and buying or renting (by the children), and capital markets are imperfect, cohabitation may be the optimal way for the young to accumulate liquid assets necessary for the down payment and in general for the 
purchase of their home.

In the case where parents and grown children live together, household decisions are unlikely to be taken in a unitary way. Even if father and mother behave as one person, and they have only one child, key household decisions are likely to be the result of some form of bargaining between parents and child. For this reason, we extend Browning's [11] "younger spouse" model to cover the case of two generations: in his model husband and wife have different survival probabilities, and therefore disagree on how much to save. In our model, the child may choose to leave home in the second period or to stay with her parents, and will base her saving decision on the preferred outcome. In either case, we can expect the child's income share to have an impact on the household saving rate.

This paper is organized as follows: Section 2 presents some basic facts on cohabitation in Europe, and on its consequences on saving rates. Section 3 presents a simple theoretical model of how composite households jointly decide how much to save and whether to continue cohabitation. Section 4 describes the two data sets used in this paper: the Italian Survey on Household Income and Wealth (SHIW) and the Dutch Socio-Economic Panel (SEP). Section 5 presents estimates for both Italy and the Netherlands, while Section 6 concludes the paper.

\section{Cohabitation across European Countries}

Economists often assume that adult children live on their own. This probably reflects the most common living arrangement that prevails in some Western countries, such as Germany, the UK or the US, where children tend to leave the parental home soon after they become of age or at least complete their education. And yet, there is ample evidence that this is by no means the rule even within Europe. Important studies by demographers have pointed out that the age of leaving home varies dramatically across European countries (Kiernan, [16] and [17], Fernández Cordón [13]). In a recent and well-documented study, Billari et al. [7] estimate that for the 10-year cohort born around 1960, for instance, median ages of leaving home were 22.5 for men and 20.5 for women in the Netherlands (very close to the UK or West Germany), as low as 20.1 for men and 19.8 for women in Lithuania, but much higher in Spain, Poland and particularly Italy (26.7 for men and 23.6 for women in Italy). This variability across countries is not a recent 
phenomenon, and suggests that institutional or cultural differences may play a lasting role in explaining international differences.

An interesting summary on cohabitation in Europe as recently as 1998 is presented in Figure 1, that shows the proportion of households in the European Community Household Panel headed by someone aged 50 or more with at least one child aged 25 or more in residence. This proportion is highest in Portugal, followed by Italy, Ireland and Spain, and lowest in Denmark, followed by the Netherlands and the UK. ${ }^{1}$

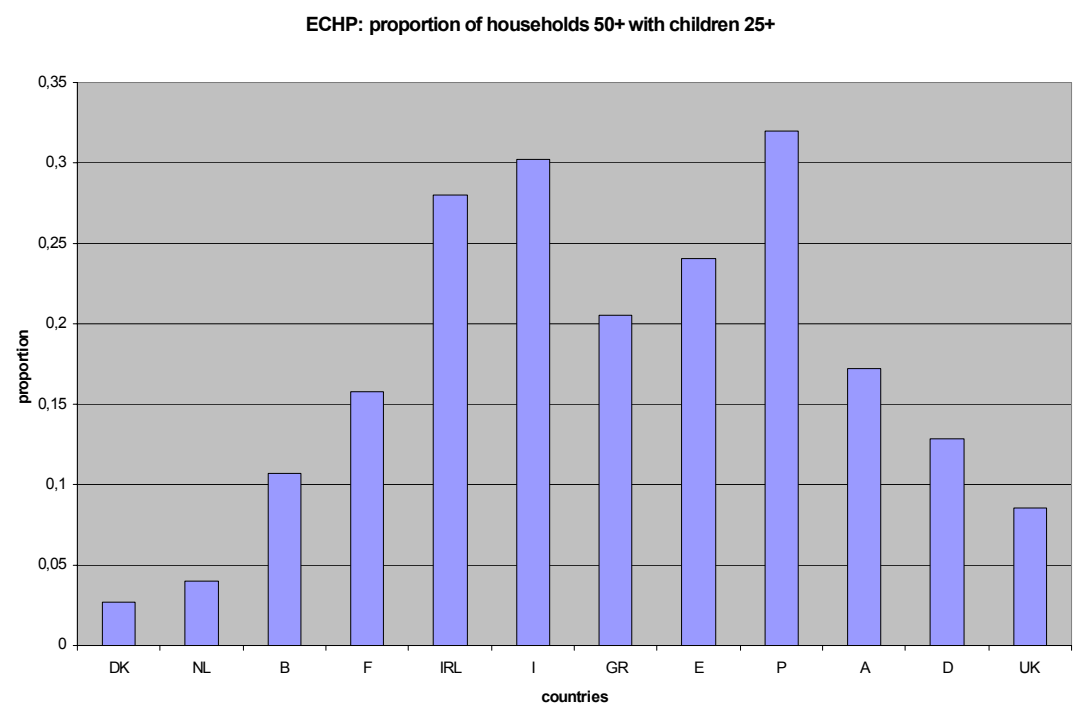

Figure 1: Proportion of composite households in European countries

However, even though in the Netherlands cohabitation of children aged $25+$ with their parents is quite rare, the cohabitation of $18-25$ is much more common. On the basis of this evidence, it makes sense to study the way cohabitation and saving decisions are taken across different countries but not necessarily to focus on a specific age group: we shall construct our empirical exercise in such a way that the leaving home decision could be taken mostly by children aged 25+ (like in Italy) or 18-25 (like in the Netherlands).

Computing saving rates in household level data is difficult. Saving can be defined as income minus expenditure, or as the change in wealth. The two definitions are not even conceptually the same, because income does not normally include capital gains (see Brugiavini and Weber [10] for a discussion of this and many other issues). But empirically, they are likely to differ 
for measurement problems too: the flow definition requires finding a survey that contains high quality data on both income and expenditure, the stock-based measure requires good records of financial and real wealth for at least two points in time.

In our empirical work, we shall use both definitions when possible (Italian data) and the stock-based measure alone when expenditure data are missing (Dutch data).

We should note that saving rates in SHIW are notoriously high, but even complex corrections based on statistical matching of complementary data sources for income and expenditure do not alter the age profile all that much (Battistin, Miniaci and Weber, [5]).

There is evidence that saving rates differ according to household type, as documented in Brugiavini and Padula [9]. In Figure 2 we show how the average saving rate varies with age in SHIW 2000, according to the nature of the household (nuclear or composite). The saving rate is higher for composite households, but the endogenous nature of the child's decision to leave home prevents a clear interpretation of this empirical regularity. A point worth noting is that household saving rates could be higher for composite households because of composition effects (if better off, high saving parents induce their children to stay with them) or because the children also earn income and save to finance their move out of the parental home.

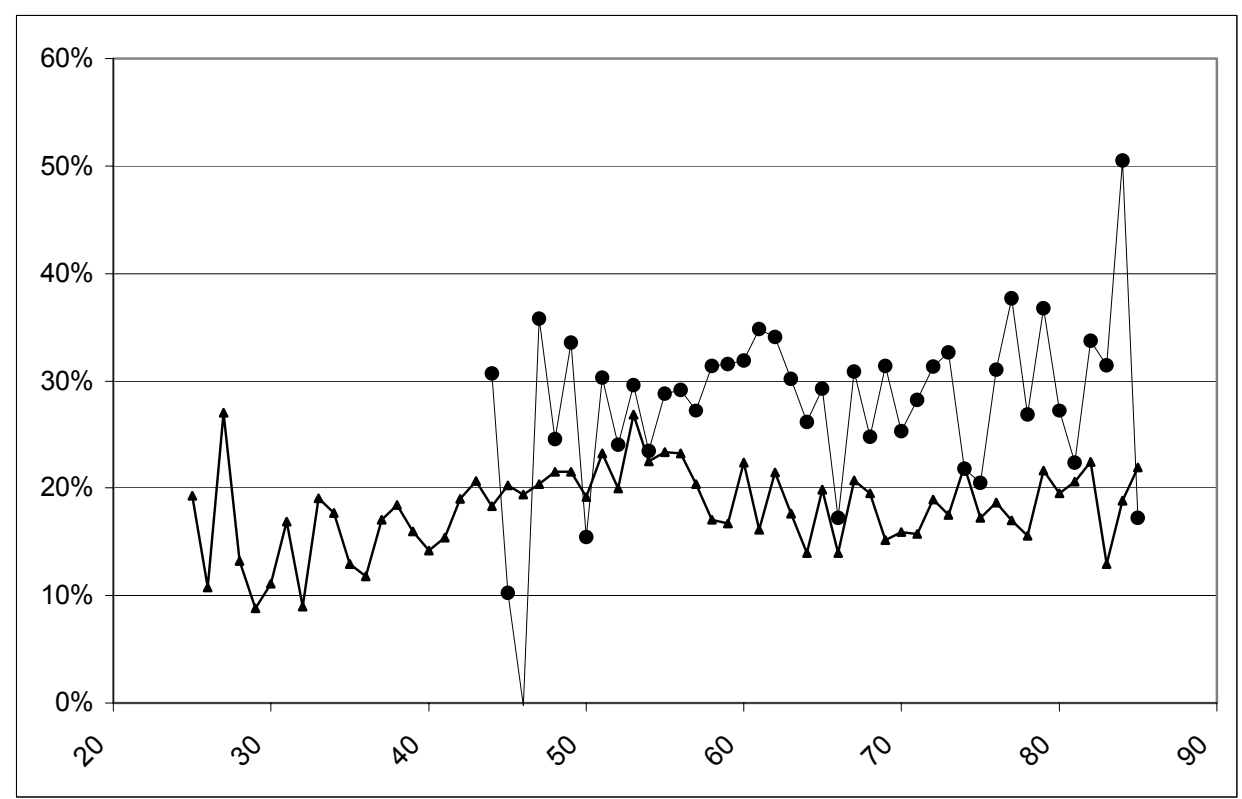

Figure 2: Saving rates by nuclear and composite households in Italy 


\section{Cohabitation and Saving: A Simple Model}

In this section we develop a simple model that can help us assess to what extent the differences in saving rates found in micro data are due to imperfections in housing and credit markets or to differences in preferences across generations. If transaction costs in the housing market are particularly high for both trading down (by the parents) and buying or renting (by the children), and capital markets are imperfect, a long period of cohabitation may be the optimal way for the young to accumulate liquid assets necessary for the down payment and in general for the purchase of their home.

In our simple model we assume that parents and children live for two periods: in period 1 all adult children live with their parents. In period 2 some will go and live on their own, some will remain with their parents. The parents behave as a unit (known as $F$ ), and they prefer their children to live with them (this is particularly true for Italy, according to Manacorda Moretti's [18] elaborations on World Value Survey data). The children prefer to live on their own, but they must pay a fixed transaction cost at the moment they leave. This could be a down-payment for home purchase, or a cash advance on rent or deposit, but it could also be moving expenses and the costs of getting furniture and basic household appliances. Similar assumptions are made by Manacorda and Moretti [18], who consider labour supply decisions of the parents in a static model. $^{2}$

Crucial to our model is the assumption that individual saving cannot be negative. This is equivalent to ruling out borrowing not only outside the household, but also within. Borrowing outside the household is unlikely to be sought by the (middle-aged) parents, whose income is relatively high, and is unlikely to be granted to the children, whose jobs are typically not secure (as stressed by Becker et al. [6]). Borrowing within the household may occur if parents want or are willing to help their children to move out, as argued by Guiso and Jappelli [15]. However, this help may well be withheld as long as possible, if parents derive utility from cohabitation. We do not model this further aspect of the inter-generational game, but note the potential importance of a strategic use of transfers from parents to children to delay independence.

We assume there is only one child for convenience, and labour supply by both parents and child is exogenous. In the model we further assume certainty. Consumption is a public good within the parents' household, but it becomes private if the child leaves home. The issue is of 
how household saving is affected by the possibility that the child moves out. The child's decision to move out is endogenous and will therefore be known for sure in period 1 . The model assumes that parents and child play a Nash game. In the case where the child decides to stay with the father this leads to a Pareto-efficient solution. In the case where she chooses to move out, this leads to an inefficient solution (too much saving, because consumption is a public good in period 1, a private good in period 2). Therefore, we shall also consider the cooperative solution for the case where the child decides to move out.

Let us denote with $F$ the parents variables, with $K$ the child variables. Let $P$ be the amount saved by the parents, $S$ be the amount saved by the child. Let $Y$ be income (with subscripts for periods 1 and 2, superscripts $F$ for parents and $K$ for the child - no superscript denotes the household total: $\left.Y_{1}=Y_{1}^{F}+Y_{1}^{K}\right)$. Consumption in period 1 is the difference between total household income and total saving $\left(Y_{1}-S-P\right)$. Let $\lambda$ be a $0-1$ indicator: $\lambda=1$ if in period 2 the child remains with her parents, $\lambda=0$ if she leaves the parents' home. Let $T$ be the transaction cost incurred if the child moves out. Finally, the constants $x$ and $z$ are both greater than unity and denote respectively the preference of the parents for cohabitation and of the child for independence.

Formally, the parents choose $P$ and the child chooses $S$ and $\lambda$ so as to maximize their utility functions that are given by:

$$
\begin{aligned}
U_{F} & =U\left(Y_{1}-S-P\right)+\lambda x U\left(P+S+Y_{2}\right)+(1-\lambda) U\left(P+Y_{2}^{F}\right) \\
U_{K} & =U\left(Y_{1}-S-P\right)+\lambda U\left(P+S+Y_{2}\right)+z(1-\lambda) U\left(S+Y_{2}^{K}-T\right)
\end{aligned}
$$

where the budget constraint is already taken into account. Liquidity constraints imply that today's savings cannot be negative. For the sake of simplicity, we shall use throughout logarithmic utility, without loss of generality.

In the sequel we are going to first show how saving decisions are taken when the child finds it advantageous to remain with her parents in the second period, then what saving is in the case where the child moves out, and finally discuss the likely determinants of the decision to stay or move out.

The case where $\lambda=1$ is chosen by the child is like Browning's "younger spouse" model (see [11]), because consumption is a public good in both periods but one agent (the parents) values 
future consumption more than the other. Thus in the Nash equilibrium the parents will be the one to save first. In this case, we can work out the dictatorial solutions for parents and child, and get:

$$
\begin{aligned}
& (P+S)_{F}=\frac{x Y_{1}-Y_{2}}{1+x} \\
& (P+S)_{K}=\frac{Y_{1}-Y_{2}}{2}
\end{aligned}
$$

and we see that, if $x>1$ then $(P+S)_{F}>(P+S)_{K}$. As in Browning [11] we can establish the following two lemmas:

Lemma 1: The saving functions of parents $(P(S))$ and child $(S(P))$ are given by:

$$
\begin{aligned}
& S(P)=\max \left[\min \left(Y_{1}^{k},(P+S)_{k}-P\right), 0\right] \\
& P(S)=\max \left[\min \left(Y_{1}^{F},(P+S)_{F}-S\right), 0\right]
\end{aligned}
$$

Lemma 2: Either the parents save all of their income $\left(Y_{1}^{F}\right)$ or the child saves none of her income $\left(Y_{1}^{K}\right)$. Hence:

$$
S\left(Y_{1}^{F}-P\right)=0
$$

Then we can establish the following

\section{Proposition 1:}

(a) The parents save all of their income if

$$
Y_{1}^{F}<(S+P)_{F} \Rightarrow P=(1-\rho) Y_{1}
$$

where $\rho$ is the child's share in period 1 income. Otherwise:

$$
P=(S+P)_{F}
$$

(b) The child saves none of her income if

$$
Y_{1}^{F}>(S+P)_{K}
$$


and otherwise saves:

$$
S=(S+P)_{K}-Y_{1}^{F}
$$

(c) total household saving is therefore given by the following:

$$
\begin{array}{ccc}
(\widehat{P}+\widehat{S})=(S+P)_{K}=\frac{Y_{1}-Y_{2}}{2} & \text { if } \quad Y_{1}^{F}<\frac{Y_{1}-Y_{2}}{2} \\
(\widehat{P}+\widehat{S})=Y_{1}^{F}=(1-\rho) Y_{1} \quad \text { if } & \frac{Y_{1}-Y_{2}}{2} \leq Y_{1}^{F}<\frac{x Y_{1}-Y_{2}}{1+x} \\
(\widehat{P}+\widehat{S})=(S+P)_{F}=\frac{x Y_{1}-Y_{2}}{1+x} & \text { if } \quad Y_{1}^{F}>\frac{x Y_{1}-Y_{2}}{1+x}
\end{array}
$$

The proposition implies that income distribution within the family affects total household saving, at least for an intermediate income range, whenever the child chooses to live with her parents in both periods. Not surprisingly, in this region a higher income share of the parents increases saving.

The case where $\lambda=0$ is less straightforward. If the child decides to move out of her parents' place, period-two consumption is a private good for both agents. The Nash solution can be found as the intersection of reaction functions, at least over a certain income range. The two reaction functions are easily derived as follows:

$$
\begin{gathered}
P=\frac{Y_{1}-Y_{2}^{F}}{2}-\frac{S}{2} \\
S=\frac{1}{1+z}\left[z Y_{1}+T-Y_{2}^{K}\right]-\frac{z}{1+z} P
\end{gathered}
$$

where the non-negativity constraints have been ignored, as well as the constraint that each agent's saving cannot exceed their current income. The solution to this system of equation is as follows:

$$
\begin{gathered}
S=\frac{2}{2+z}\left(z Y_{1}+T-Y_{2}^{K}-\frac{z}{2}\left(Y_{1}-Y_{2}^{F}\right)\right) \\
P=\frac{Y_{1}-Y_{2}^{F}}{2}-\frac{1}{2+z}\left(z Y_{1}+T-Y_{2}^{K}-\frac{z}{2}\left(Y_{1}-Y_{2}^{F}\right)\right)
\end{gathered}
$$

and the sum of the two simplifies to the following expression: 


$$
P+S=\frac{(1+z) Y_{1}+T-Y_{2}^{K}-Y_{2}^{F}}{2+z}
$$

and this does not depend on period 1 income distribution within the household. However, this interior solution does not hold for all possible income values.

We can establish that parents save less than the child as long as period 1 household income is sufficiently large compared to parents' income in period 2 and child's income net of transaction cost. This condition seems reasonable in view of the fact that $Y_{1}$ subsumes initial wealth of both agents.

Then the interesting case to investigate is the one where $Y_{1}^{K}<S$. In this case the child saves all of her income, whereas the parents saves according to equation (5), that is:

$$
P=\frac{Y_{1}-Y_{2}^{F}}{2}-\frac{Y_{1}^{K}}{2}=\frac{(1-\rho) Y_{1}-Y_{2}^{F}}{2}
$$

and total household saving is:

$$
P+S=\frac{Y_{1}-Y_{2}^{F}}{2}+\frac{Y_{1}^{K}}{2}=\frac{Y_{1}-Y_{2}^{F}}{2}+\frac{\rho Y_{1}}{2}
$$

In this case, total household saving is positively affected by $\rho$, the child's share in period 1 income. However, this outcome is not Pareto-efficient, because there is more saving than any collective solution would imply (period 1 consumption is a public good, period 2 consumption is private, so the two agents under-provide the public good and save more than in the efficient solution).

The child can work out whether her utility is higher under cohabitation or under independence. The preference for independence (represented by the $z$ parameter in equation (2)) will push her to leave home; the transaction cost and her parents' preference for cohabitation (represented by the $x$ parameter in equation (1)) will instead act in the opposite direction.

We can work out what the Pareto-efficient solution will be in the case of independence. This will serve us as a benchmark to assess the welfare loss associated to the non-cooperative solution of equation (9), but is also interesting because it is the relevant solution if the two generations decide to cooperate (as argued in much of the recent literature on household decision making, see Vermeulen (2003)). In the case where $\lambda=0$ the efficient solution can be found by choosing 
$P$ and $S$ so as to maximize the following criterion function:

$$
U_{\mu}=U\left(Y_{1}-S-P\right)+\mu U\left(P+Y_{2}^{F}\right)+z(1-\mu) U\left(S+Y_{2}^{K}-T\right)
$$

where $\mu$ is the Pareto-weight attached to the parents' utility. This will normally be a decreasing function of $\rho$, the child's share in period 1 income, as individual incomes affect the fall-back position of the Nash bargaining solution. Of course $\mu$ can also be a function of other exogenous characteristics.

Under logarithmic utility and ignoring inequality constraints, this leads to the following solution:

$$
\begin{aligned}
& \hat{S}=\frac{1}{1+\mu+z(1-\mu)}\left[(1-\mu) z\left(Y_{1}+Y_{2}^{F}\right)-(1+\mu)\left(Y_{2}^{K}-T\right)\right] \\
& \hat{P}=\frac{1}{1+\mu+z(1-\mu)}\left[\mu Y_{1}-(1+z(1-\mu)) Y_{2}^{F}+\mu\left(Y_{2}^{K}-T\right)\right]
\end{aligned}
$$

and total household saving is:

$$
\hat{S}+\hat{P}=\frac{1}{1+\mu+z(1-\mu)}\left[((1-\mu) z+\mu) Y_{1}-Y_{2}^{F}-\left(Y_{2}^{K}-T\right)\right]
$$

We can see that if $z=1$ total household saving does not depend on $\mu$ or on how income is allocated in period 1 . This simply says that if the two agents agree the cooperative solution is unique and independent of the Pareto weights.

The interesting case is when $z>1$, that is when the child values independence more. Let us define $\xi=z-1$ and write the solution as a function of $\xi$ :

$$
\hat{S}+\hat{P}=\frac{1}{2+\xi(1-\mu)}\left[(1+\xi(1-\mu)) Y_{1}-Y_{2}^{F}-\left(Y_{2}^{K}-T\right)\right]
$$

and we easily check that its derivative with respect to $\mu$ is negative as long as $\xi$ is positive and total period 2 household income exceeds the transaction cost. Both conditions are easily met.

If $\mu$ is a decreasing function in $\rho$ (the parents' Pareto weight is smaller when the child has more income), this implies that a higher period 1 income share of the child increases household saving.

To summarize, we have found the following: 
- the child is more likely to move out if the transaction cost is low and if her preference for independence is high. Also the parents' preference for cohabitation may have a negative effect if the parents' period 1 income is sufficiently high (see proposition 3 )

- if the child decides to stay home, a higher period 1 income share for her either has no effect on household saving, or a negative effect

- if the child decides to leave home, and parents and child play a Nash game, then a higher period 1 income share for the child either has no effect on household saving, or a positive effect. However, the Nash game leads in this case to a Pareto inefficient solution

- if the child decides to leave home, and parents and child play a cooperative game instead, then a higher period 1 income share for the child has again a positive effect.

Similar effects of period 1 child's income share are found for the saving rate.

The case where the child prefer cohabitation, and parents would like her to leave home, can to an extent be modeled by making $x$ and $z$ less than unity. But, given the presence of transaction costs and other penalties attached to living on her own (loss of public consumption), the child will never leave her parental home, unless forced to or bribed by her parents. This suggests that in this case the assumption of no inter-vivos tranfers is clearly not tenable (after all, most children leave home eventually!). A more general model is needed that is beyond the scope of this paper.

The main conclusions of our model are unaffected if the child living with her parents can spend money on a private consumption good, as long as she also consumes some of the public good.

\section{The Data}

In this paper we use household survey data from two European countries: Italy and the Netherlands. The micro data we use are taken from SHIW for Italy, from SEP for the Netherlands and are described in the rest of this section.

As figure (1) reveals, in Italy over $30 \%$ of households whose head is over 50 have at least one child aged 25 or more in residence. In the Netherlands this proportion is much smaller (less than 
$5 \%$ ), but in recent years there has been an increase in the number of young Dutch (aged 18-24) who live with their parents, possibly because of increased house prices and rents or decreased welfare benefits for young people.

The workings of housing and credit markets are quite different in the two countries, as documented in Chiuri and Jappelli (2000): for instance, over the 1986-96 decade in Italy the ratio of outstanding mortgage debt to GDP was a meager $5.30 \%$, whereas in the Netherlands the same ratio was $43.29 \%$. According to the same source, over the 1990-95 period the downpayment ratio was $40 \%$ in Italy, $25 \%$ in the Netherlands (it is now lower in both countries, but still higher in the Netherlands than in Italy). Housing rental markets are heavily regulated in both countries, thus making it hard for outsiders to find rented accommodation However, University and Local Authorities housing exists in the Netherlands to a much larger extent than in Italy, so that single young people have a reasonable chance of finding an apartment to rent as long as they do not plan to live in a town other than their own or their University's.

To assess the extent to which renting is more widespread among the young in the Netherlands than in Italy, in Table 1 we show the proportion of individuals in different types of living arrangements in the two countries. The Table shows that young Dutch typically rent (particularly in the 20-24 age range) and then move on to purchasing their home (in the 30-34 age range almost $70 \%$ are home owners). Italians instead not only move out at later ages, but also make less use of rented accommodation early on. However, at a later stage (between 30 and 39 years of age), the fractions of renters and owners are of comparable size, while home-ownership prevails past age 40 .

\subsection{The Italian Data: SHIW}

The Italian Survey on Household Income and Wealth (SHIW) is run by Bank of Italy, and documented in a number of papers. The primary purpose of SHIW is to collect detailed data on demographics, households' consumption, income and balance sheets. The SHIW surveys a representative sample of the Italian resident population. From 1987 onward the survey has been conducted every other year (with one exception) and covers about 8,000 households, defined as groups of individuals related by blood, marriage or adoption and sharing the same dwelling. The most recent wave of SHIW was conducted in the spring of 2003, and contains information on 2002. However, SHIW contains a rotating panel component: for instance, about half the 
Table 1: Living arrangements by age

\begin{tabular}{|c|c|c|c|c|c|c|}
\hline & \multicolumn{3}{|c|}{ Italy } & \multicolumn{3}{c|}{ NL } \\
\hline Age & WithParents & Own & Rent & With Parents & Own & Rent \\
\hline $16-19$ & 1.00 & 0.00 & 0.00 & 0.96 & 0.00 & 0.04 \\
\hline $20-24$ & 0.96 & 0.02 & 0.02 & 0.57 & 0.13 & 0.30 \\
\hline $25-29$ & 0.82 & 0.06 & 0.12 & 0.11 & 0.49 & 0.39 \\
\hline $30-34$ & 0.49 & 0.27 & 0.24 & 0.02 & 0.69 & 0.29 \\
\hline $35-39$ & 0.22 & 0.44 & 0.34 & 0.02 & 0.76 & 0.22 \\
\hline $40-44$ & 0.12 & 0.56 & 0.32 & 0.01 & 0.75 & 0.24 \\
\hline $45-49$ & 0.05 & 0.64 & 0.31 & 0.01 & 0.72 & 0.27 \\
\hline $50-54$ & 0.05 & 0.72 & 0.22 & 0.00 & 0.70 & 0.30 \\
\hline $55-59$ & 0.02 & 0.77 & 0.21 & 0.00 & 0.70 & 0.29 \\
\hline $60-64$ & 0.01 & 0.79 & 0.19 & 0.00 & 0.65 & 0.35 \\
\hline $65-69$ & 0.00 & 0.79 & 0.21 & 0.00 & 0.48 & 0.52 \\
\hline $70-74$ & 0.00 & 0.74 & 0.26 & 0.00 & 0.45 & 0.55 \\
\hline $75-79$ & 0.00 & 0.72 & 0.28 & 0.00 & 0.32 & 0.68 \\
\hline $80+$ & 0.00 & 0.65 & 0.35 & 0.00 & 0.26 & 0.74 \\
\hline
\end{tabular}


2002 sample had already taken part in the 2000 survey, and this is the sample we use. The net response rate (the ratio of responses to families contacted net of ineligible units) in 2000-2002 was 74.5 percent. See Brandolini and Cannari [8] for more details on the survey.

In this survey saving can be computed in two different ways: The standard flow definition as disposable income minus expenditure, and the change in wealth definition. These two definitions are not conceptually the same: the former typically excludes capital gains, that may be particularly relevant in the case of real wealth, but also risky financial wealth (stocks and shares), the latter does include capital gains, but does not distinguish between various forms of wealth, that may differ in liquidity and fungibility. Further differences may be tracked to the way information is collected: expenditure records are based on recall questions, and thus typically underestimated; financial wealth is also under-reported in SHIW, and pension wealth is neglected altogether. ${ }^{3}$

In SHIW detailed information is available on household members, including their income, age, education, sex, and relation to the head. However, wealth is considered a household-level variable, and so is consumption. As for children of the head who do not live with their parents, all we know is their existence and number. We also have some information on the head's parents (such as how far they live, and their education attainment). Wealth is recorded as of the end of the calendar year, while flows refer to the whole year.

SHIW 2002 has records on 8010 households. In all specifications, we need to condition on beginning of period wealth: to do this we must take wealth as recorded in SHIW 2000. Of all 8010 households interviewed in SHIW 2002, 3604 were also present in SHIW 2000. Given our interest in grown children, we further select the estimation sample according to the following criteria: the head must be aged 40 years or more and must have at least one child (whether in residence or not).This leaves 2662 observations. Finally, given that children aged less than 16 are unlikely to move out in the near future, we also drop those households who report having no children outside and whose oldest child at home is younger than 16 years of age. The final estimation sample contains 2411 observations, 1426 of which have at least one child living at home. 


\subsection{The Dutch data: SEP}

We use data from the Socio-Economic Panel (SEP). The SEP is a longitudinal survey administered by Statistics Netherlands (CBS) consisting of approximately 5,000 households. The purpose of the SEP is to provide a description of the most important elements of individual and household welfare and to monitor changes in these elements. The SEP has been launched in April 1984. The same households were interviewed in October 1984 and then twice a year (in April and October) until 1989. Since 1990 the survey has been conducted once a year in May. In this research we mainly use data from the 1994-2001 waves because they contain information on perceived job security and satisfaction with housing arrangements.

The survey is representative of the Dutch population, excluding those living in special institutions like nursing homes. In order to arrive at a representative sample, Statistics Netherlands has applied a two-stage sampling procedure to collect the initial April 1984 sample. In the first stage, municipalities are drawn with probabilities depending on the number of inhabitants (big cities are drawn with certainty). In the second stage, addresses are selected randomly. All households present at the selected address are interviewed, up to a maximum of three households. The initial rate of unit-non response was equal to $50 \%$. In order to address the problem of sample attrition, from 1986 onwards Statistics Netherlands regularly adds new households to the SEP. The yearly attrition rate is equal to about $10 \%$. In order to keep the sample as representative as possible, Statistics Netherlands refreshes the sample by replacing those households who have left the sample by 'similar' households. In case of refreshment samples the rate of unit-non-response is equal to about $65 \%$.

In the October interviews, information has been collected at the respondent level ${ }^{4}$ on socioeconomic characteristics, income and labor market participation. The April interviews also contain information about socio-economic characteristics, but rather than gathering data about income, since 1987 the April questionnaires have included questions on a wide range of assets and liabilities. In this paper, we present summary statistics on net worth, financial wealth, and real wealth. Net worth is obtained by subtracting total liabilities from total assets. We also analyze financial wealth holdings. Financial wealth has been defined as the difference between net worth on the one hand and housing equity (value of the primary residence plus life insurance mortgage minus remaining mortgage debt), other real estate and the value of the cars on the 
other hand. Real wealth is defined to be the difference between net worth and financial wealth.

From the 1990 wave onwards, the SEP collects for most income components information on 'gross income' of the previous calendar year. Alessie and Kapteyn [1] provide details on how disposable income can be calculated. The SEP does not contain information on consumption expenditures. As a result of this, the SEP can only measure saving by taking the first difference of net worth. This saving measure therefore includes (unrealized) capital gains.

Every respondent (i.e., a person who is at least 16 years old) in the household has to complete a short questionnaire on assets and liabilities. However, the SEP does not contain information on cash holdings and on occupational pension wealth. For this study we have removed the self-employed from the sample because from 1990 onwards no wealth data have been collected for this group. Financial wealth has been defined as the difference between net worth on the one hand and housing equity (value of the primary residence plus life insurance mortgage minus remaining mortgage debt), other real estate and the value of the cars on the other hand.

To calculate net worth at the household level, we have chosen the following criteria (this refers to the data after imputation): we exclude observations for which (i) the head of the household or the spouse "refuses to answer" one or more questions about their assets or debts; or (ii) at least one respondent answers with "do not know" to one or more questions about his/her assets and debt. After removing the self-employed from the sample, it is possible to calculate net worth for approximately $95 \%$ of the households, more than in previous years (samples in the late 1980s show some evidence of selectivity, as discussed in Alessie, Lusardi and Aldershof [2]). It appears that item non-response is especially relevant for saving and checking accounts. No attempts have been made to impute the missing values. It is worth stressing that child financial wealth is (where recorded) mostly positive, with a median value of 1700 Dfl (Dutch Guilders. All monetary values are at 1990 prices. At the time, the exchange rate was $1 \$=1.61 \mathrm{Dfl})$ ). Zeros are recorded in only $9 \%$ of the cases. For comparison, median household financial wealth in the same sample is 13000 Guilders .

The data set does not contain information on children outside the parental home, but does follow a large number of households through a relatively long time period. This allows us to estimate the probability that any child leaves home as a function of both child's and parents' characteristics. The selection criterion we adopt is that the child must have been at least 17 years old in year $t$ (where $t=1994,1995, \ldots, 2000$ ). In our sample we have a total of 5102 observations, 
but for only 3015 of these we have valid records of the relevant variables (unfortunately not all children aged 16 or more accept filling in their questionnaire). This is a truncated sample by definition: in the smaller sample (3015 observations) there are 1257 children, belonging to 894 households. The exit rate (that is: the proportion of children who are at home at $t$ but leave home at $t+1$ ) is higher for women than for men, and is monotonically increasing in age between 17 years of age (when is 7.0\%) and 25 (when it peaks at 32\%). Absolute numbers of children who leave home peak at age 18 (126 home leavers), but remain higher than 70 up to age 23 . Relatively few individuals live with their parents past age 25, as already noted in Section 2 (less than $5 \%$ of the 5102 observations correspond to children of such age). 


\begin{tabular}{|c|c|c|c|}
\hline & Marginal effects probit & ()IS & Child fixed effects \\
\hline Age & $\begin{array}{c}1.244 \\
(0.140)^{* 4}\end{array}$ & $\begin{array}{c}1.106 \\
(0.106)^{* 4}\end{array}$ & $\begin{array}{c}1.416 \\
(0.37 .3)^{* 4}\end{array}$ \\
\hline $\mathrm{Age}^{2}$ & $\begin{array}{c}-0.230 \\
(0.020) * * *\end{array}$ & $\begin{array}{c}-0.196 \\
(0.010)^{* * *}\end{array}$ & $\begin{array}{l}-0.010 \\
(0.070)\end{array}$ \\
\hline Female & $\begin{array}{c}0.099 \\
(0.014)^{* 10}\end{array}$ & $\begin{array}{c}0.096 \\
(0.013)^{* * *}\end{array}$ & $\begin{array}{l}0.000 \\
(0.000)\end{array}$ \\
\hline Income share child & $\begin{array}{c}0.016 \\
(0.014)\end{array}$ & $\begin{array}{c}0.004 \\
(0.001)^{\psi \psi}\end{array}$ & $\begin{array}{c}0.002 \\
(0.005)\end{array}$ \\
\hline Main activity= study & $\begin{array}{l}0.010 \\
(0.019)\end{array}$ & $\begin{array}{c}0.006 \\
(0.020)\end{array}$ & $\begin{array}{l}0.003 \\
(0.029)\end{array}$ \\
\hline $\begin{array}{l}\text { Satisfaction with housing situation: Very } \\
\text { disoutisfied }\end{array}$ & $\begin{array}{c}0.146 \\
(0.1(19)\end{array}$ & $\begin{array}{l}0.142 \\
(0.1(4)\end{array}$ & $\begin{array}{l}0.151 \\
(0.117)\end{array}$ \\
\hline Sat isfaction with housing situation: dissatisfied & $\begin{array}{c}0.180 \\
(0.078)^{*}\end{array}$ & $\begin{array}{c}0.171 \\
(0.070)^{*}\end{array}$ & $\begin{array}{l}0.101 \\
(0.072)\end{array}$ \\
\hline $\begin{array}{l}\text { Sat isfaction with housing situation: } \\
\text { A bit dissatisfied }\end{array}$ & $\begin{array}{c}0.115 \\
(0.040)^{\text {*he }}\end{array}$ & $\begin{array}{c}0.12 j \\
(0.040)^{* * *}\end{array}$ & $\begin{array}{c}0.094 \\
(0.042)^{*}\end{array}$ \\
\hline $\begin{array}{l}\text { Satisfaction with housing situation: } \\
\text { A hit satisfied }\end{array}$ & $\begin{array}{c}0.021 \\
(0.020) \\
\end{array}$ & $\begin{array}{c}0.022 \\
(0.021) \\
\end{array}$ & $\begin{array}{c}0.024 \\
(0.025) \\
\end{array}$ \\
\hline Salisfaction with housing situation: Very satisfied & $\begin{array}{c}-0.0 .31 \\
(0.014)^{*}\end{array}$ & $\begin{array}{c}-0.0 .32 \\
(0.014)^{\psi}\end{array}$ & $\begin{array}{l}-0.006 \\
(0.019)\end{array}$ \\
\hline $\begin{array}{l}\text { Satisfaction with joh security } \\
\text { Questimn not answered (not working) }\end{array}$ & $\begin{array}{l}-0.010 \\
(0.019)\end{array}$ & $\begin{array}{l}-0.017 \\
(0.020) \\
\end{array}$ & $\begin{array}{c}0.004 \\
(0.028)\end{array}$ \\
\hline $\begin{array}{l}\text { Satisfaction with job security } \\
\text { Very dissatisfied }\end{array}$ & $\begin{array}{c}-0.091 \\
(0.022)^{* 4}\end{array}$ & $\begin{array}{c}-0.123 \\
(0.0 .36)^{44}\end{array}$ & $\begin{array}{l}-0.086 \\
(0.0 .51)\end{array}$ \\
\hline $\begin{array}{l}\text { Sat isfaction with joh security } \\
\text { Dissatisfied }\end{array}$ & $\begin{array}{l}-0.012 \\
(0.036)\end{array}$ & $\begin{array}{l}-0.020 \\
(0.046)\end{array}$ & $\begin{array}{l}-0.007 \\
(0.051)\end{array}$ \\
\hline $\begin{array}{l}\text { Satisfaction with job security } \\
\Lambda \text { bil dissatisfied }\end{array}$ & $\begin{array}{l}-0.025 \\
(0.026)\end{array}$ & $\begin{array}{l}-0.030 \\
(0.033)\end{array}$ & $\begin{array}{l}-0.011 \\
(0.030)\end{array}$ \\
\hline $\begin{array}{l}\text { Sat isfaction with job security } \\
\text { A bit satisfled }\end{array}$ & $\begin{array}{c}-0.066 \\
(0.01 .8)^{\text {a. }}\end{array}$ & $\begin{array}{l}-0.082 \\
(0.02 .5)^{4.4}\end{array}$ & $\begin{array}{l}-(0.020) \\
(0.0 .30)\end{array}$ \\
\hline Other head of household: yes & $\begin{array}{l}-0.035 \\
(0.077) \\
\end{array}$ & $\begin{array}{l}-0.051 \\
(0.110)\end{array}$ & $\begin{array}{l}0.003 \\
(0.122) \\
\end{array}$ \\
\hline Age houschold head & $\begin{array}{l}-0.001 \\
(0.002)\end{array}$ & $\begin{array}{l}-0.001 \\
(0.002)\end{array}$ & $\begin{array}{l}-0.026 \\
(0.020)\end{array}$ \\
\hline Age spouse & $\begin{array}{l}-0.002 \\
(0.002)\end{array}$ & $\begin{array}{l}-0.003 \\
(0.002)\end{array}$ & $\begin{array}{l}-0.018 \\
(0.011)\end{array}$ \\
\hline No spouse & $\begin{array}{l}-0.078 \\
(0.061) \\
\end{array}$ & $\begin{array}{l}-0.118 \\
(0.082) \\
\end{array}$ & $\begin{array}{l}-0.065 \\
(0.509) \\
\end{array}$ \\
\hline Household income & $\begin{array}{c}1.004 \\
(0.320))^{\mathrm{k}}\end{array}$ & $\begin{array}{c}1.086 \\
(0.360)^{4 *}\end{array}$ & $\begin{array}{l}-0.566 \\
(0.940) \\
\end{array}$ \\
\hline HH Fïnancial wealth & $\begin{array}{l}0.052 \\
(0.110)\end{array}$ & $\begin{array}{l}0.062 \\
(0.11 .5) \\
\end{array}$ & $\begin{array}{l}0.178 \\
(0.2 .31) \\
\end{array}$ \\
\hline Real wealth & $\begin{array}{l}-0.042 \\
(0.048)\end{array}$ & $\begin{array}{l}-0.019 \\
(0.011)\end{array}$ & $\begin{array}{l}0.00 .5 \\
(0.028)\end{array}$ \\
\hline Home nize & $\begin{array}{l}-0.001 \\
(0.007)\end{array}$ & $\begin{array}{l}-0.00 .3 \\
(0.007)\end{array}$ & $\begin{array}{l}-0.022 \\
(0.018)\end{array}$ \\
\hline IIome size per capila & $\begin{array}{l}0.017 \\
(0.019)\end{array}$ & $\begin{array}{l}0.019 \\
(0.020)\end{array}$ & $\begin{array}{l}-0.00(4) \\
(0.0 .5 .5)\end{array}$ \\
\hline $\begin{array}{l}\text { Fin. Situation HH last } 12 \text { months "has improved a } \\
\text { lot" }\end{array}$ & $\begin{array}{l}0.032 \\
(0.034)\end{array}$ & $\begin{array}{l}0.028 \\
(0.033)\end{array}$ & $\begin{array}{l}0.025 \\
(0.040)\end{array}$ \\
\hline Fin. Situation "has improved a bit" & $\begin{array}{c}0.042 \\
(0.017)^{*}\end{array}$ & $\begin{array}{c}0.040 \\
(0.018)^{*}\end{array}$ & $\begin{array}{l}0.0 .33 \\
(0.021) \\
\end{array}$ \\
\hline Fin. Situation "has deferiorated a bit" & $\begin{array}{l}-0.029 \\
(0.018)\end{array}$ & $\begin{array}{l}-0.030 \\
(0.017)\end{array}$ & $\begin{array}{l}-0.024 \\
(0.023)\end{array}$ \\
\hline Fin. Siluation "has deterioraled a lot" & $\begin{array}{l}0.061 \\
(0.036)\end{array}$ & $\begin{array}{l}0.050 \\
(0.033)\end{array}$ & $\begin{array}{l}0.067 \\
(0.039)\end{array}$ \\
\hline Constant & & $\begin{array}{l}-1.19 .3 \\
(0.139)^{4 * *}\end{array}$ & $\begin{array}{l}-0.408 \\
(0.694)\end{array}$ \\
\hline Observalions & 3994 & 3014 & .3014 \\
\hline p-value $\chi^{\prime}$-test satisfaction job sccurity & 0.0014 & 0.0() 1 & 0.5 .36 \\
\hline$p$-value $\chi^{2}$-test fin. siluation last 12 months & 0.001 & 0.004 & 0.09 .5 \\
\hline$p$-value $\chi^{7}$-lest satisfaction housing siluation & 0.000 & 0.000 & 0.163 \\
\hline log-likelihood/ $R^{2}$ & -1197.555 & 0.08 & 0.19 \\
\hline \multicolumn{4}{|c|}{ Robust standard errors in parentheses $\quad$ "significant at $5 \%$; } \\
\hline
\end{tabular}

Table 2: Probability the child leaves home - SEP (3044 observations) 20 
An interesting exercise involves estimating the probability of leaving home in period $(t+1)$, conditional on child's and parents' characteristics as of period $t$. Estimation results are presented in Table 2. In Column (1) we report marginal effects of a Probit specification, in column (2) corresponding effects estimated by OLS (linear probability model). In both cases standard errors take clustering into account. Column (3) presents a fixed effect specification instead, that is a specification that allows for child-specific intercepts (and relies on time variability for identification).

The Table shows that estimation differences between columns (1) and (2) are relatively minor. We shall therefore comment on Column (2) estimates, that are directly comparable to Column (3). The explanatory variables are divided in two groups: those that relate to the child (upper panel), and those that relate to either the parents or the head ( $\mathrm{HH}$, lower panel)). In the first group, we have age and age squared (the conditional probability peaks at 28 years according to column 2 estimates), gender (females are $9.6 \%$ more likely to leave), the share of child's income and financial wealth to household income and financial wealth (this has a positive and significant effect according to the linear probability model, positive and insignificant according to the probit model), self-reported satisfaction variables on housing and job security. The housing satisfaction coefficients suggest that children are more likely to leave home if they are dissatisfied or somewhat dissatisfied with their housing situation. Small and insignificant effects are found for those who are very dissatisfied, a negative and significant effect is estimated for those who are very satisfied (the control group are those who report being satisfied). Satisfaction with job security has strong negative effects if the child is very dissatisfied or a bit satisfied. Most household variables do not appear significant in columns (1) or (2). Notable exceptions are household income (positive effect) and the dummies indicating if the financial situation has changed over the last 12 months: minor improvements have a positive effect on the exit probability. Extreme changes do not have a significant impact, though. Column (3) estimates are largely insignificant but similar to those in column (2), suggesting that most variability in the data is cross-sectional. An exception is the coefficient on age. This variable changes meaning in column (3) compared to column (2), given that fixed effect regressions are similar to regressions in first differences: observations where the change in age is not one are few, and correspond such major event as divorce or death of a partner. 


\section{Estimation Results}

The theoretical model presented above suggests that household saving is a function of the child's income share. This contrasts with the unitary model, that assumes income pooling. Household saving should increase with the child's income share if the child intends to leave her parental home eventually, decrease otherwise. The same conclusion holds for the saving rate, a more interesting variable for economic analysis.

In the sequel we present estimation results for the two countries under investigation. Care should be taken in interpreting results because of differences between the two samples. For Italy, we use the 2002 cross section (with information on 2000 wealth) to see how the household saving rate is affected, among other things, by the child's income share. We estimate over the subsample of households with at least one child at home, and correct for endogenous selectivity using relevant information that is available for all households. Given that we know very little about children who live on their own (just their total number), the information used to estimate this probability is at the household level. For the Netherlands, we have no information on the existence and number of children outside the parental home, but we are able to follow children over time (7 years at most) as long as they stay with their parents. Notably, we know their income and their financial wealth (wealth is recorded at the household level in the Italian data), and can therefore consider changes in household wealth as well as in child wealth. Separate saving rate equations can be estimated for leavers and stayers, after correcting for endogenous selectivity.

In our empirical exercise on Italian data, we define the saving rate as the difference between disposable income (the sum of net personal incomes by head, spouse and oldest child) and nondurable consumption, divided by non-durable consumption. ${ }^{5}$ We model the saving rate in 2002 as a linear function of previously accumulated wealth (measured as total wealth and real wealth at the end of year 2000), the ages of head and spouse, household composition variables (such as the total number of household members, including children who left home, the number of resident household members, the number of resident children aged less than 25 , the number of pensioners, a dummy indicating the presence of the head's spouse and another indicating whether the oldest child is a full-time student), by broad regional dummies and by total disposable income (defined as above). We also add to the explanatory variables the child's income share variable that is 
computed as the ratio of personal income of the oldest child to total disposable income. This variable takes a positive value in 729 cases: in particular, income is positive for 54 full time students (out of 477) and for 675 other children living with their parents (out of 949). We find that in our estimation sample the child's income share exceeds the $20 \%$ mark in 605 cases (out of 1426). It is worth stressing that we have no information on wealth at the individual level, so we must take the child's income as an indicator of total resources available to her.

In the empirical implementation, we also have to address the issue of endogenous sample selectivity, because our saving rate sample is made of those households with at least one child in residence. In fact, we do not observe characteristics of children who left their parents' home, but for their total number. From our theoretical model we know that saving and cohabitation decisions are both endogenous and likely to correlate.

For this reason we follow the standard Heckman's procedure, and model the probability of observing at least one child living in a household belonging to the estimation sample as a function of variables that determine saving (except those that refer to resident children) but also of variables that should only affect the cohabitation decision. We assume that total and per-capita home size have an effect on this probability, and that the age the parent became independent (started working) is also relevant. The home size variables capture local housing conditions (thus the transaction costs of moving out), whereas the age the head became independent captures the taste for independence by both generations. 


\begin{tabular}{|c|c|c|c|}
\hline & (1) & (2) & (3) \\
\hline & $\begin{array}{l}\text { Saving rate } \\
\text { (flow } \\
\text { definition) }\end{array}$ & $\begin{array}{l}\text { Saving rate } \\
\text { (change in } \\
\text { fin. wealth) }\end{array}$ & $\begin{array}{l}\text { Probability of at } \\
\text { least one child at } \\
\text { home }\end{array}$ \\
\hline Total Wealth (2000) /100 & $\begin{array}{c}-0.0350 \\
(0.0165)^{*}\end{array}$ & $\begin{array}{c}-4.5476 \\
(0.1974) * *\end{array}$ & $\begin{array}{c}0.0480 \\
(0.0409)\end{array}$ \\
\hline Real Wealth (2000) /100 & $\begin{array}{c}0.0081 \\
(0.0182) \\
\end{array}$ & $\begin{array}{c}4.9267 \\
(0.2175) * *\end{array}$ & $\begin{array}{l}-0.0395 \\
(0.0447) \\
\end{array}$ \\
\hline Head's Age & $\begin{array}{l}-0.0074 \\
(0.0043)\end{array}$ & $\begin{array}{c}-0.1226 \\
(0.0518)^{*}\end{array}$ & $\begin{array}{c}-0.0490 \\
(0.0047)^{* *}\end{array}$ \\
\hline Spouse's Age & $\begin{array}{l}-0.0065 \\
(0.0035) \\
\end{array}$ & $\begin{array}{l}-0.0322 \\
(0.0428) \\
\end{array}$ & $\begin{array}{c}-0.0441 \\
(0.0063) * *\end{array}$ \\
\hline No Spouse & $\begin{array}{c}-0.4763 \\
(0.2159)^{*}\end{array}$ & $\begin{array}{l}-2.0178 \\
(2.5991)\end{array}$ & $\begin{array}{c}-2.8815 \\
(0.3883) * *\end{array}$ \\
\hline Total Family Size & $\begin{array}{c}0.0568 \\
(0.0189) * *\end{array}$ & $\begin{array}{c}0.3991 \\
(0.2284)\end{array}$ & $\begin{array}{c}0.1109 \\
(0.0429) * *\end{array}$ \\
\hline Northern Italy & $\begin{array}{c}-0.2503 \\
(0.0378) * *\end{array}$ & $\begin{array}{c}0.1627 \\
(0.4539)\end{array}$ & $\begin{array}{c}-0.2196 \\
(0.0756) * *\end{array}$ \\
\hline Central Italy & $\begin{array}{c}-0.2280 \\
(0.0409) * *\end{array}$ & $\begin{array}{l}-0.1265 \\
(0.4896)\end{array}$ & $\begin{array}{l}-0.0303 \\
(0.0887) \\
\end{array}$ \\
\hline Number of pensioners & $\begin{array}{l}-0.0529 \\
(0.0291)\end{array}$ & $\begin{array}{l}-0.1508 \\
(0.3503)\end{array}$ & $\begin{array}{c}-0.1874 \\
(0.0550) * *\end{array}$ \\
\hline Family Size (resident) & $\begin{array}{c}-0.1405 \\
(0.0241) * *\end{array}$ & $\begin{array}{c}0.1593 \\
(0.2959)\end{array}$ & \\
\hline Total personal income $/ 100$ & $\begin{array}{c}2.3424 \\
(0.1010) * *\end{array}$ & $\begin{array}{c}1.6441 \\
(1.2110)\end{array}$ & \\
\hline Income share of oldest child & $\begin{array}{c}0.2702 \\
(0.0752) * *\end{array}$ & $\begin{array}{l}-1.2067 \\
(0.9230)\end{array}$ & \\
\hline Number of children $<24$ & $\begin{array}{c}0.0411 \\
(0.0251)\end{array}$ & $\begin{array}{l}-0.2686 \\
(0.3047)\end{array}$ & \\
\hline Oldest child is a student & $\begin{array}{c}-0.1152 \\
(0.0391) * *\end{array}$ & $\begin{array}{l}-0.7729 \\
(0.4737)\end{array}$ & \\
\hline $\begin{array}{l}\text { Income of Head and Spouse } \\
/ 100\end{array}$ & & & $\begin{array}{c}0.3966 \\
(0.3037) \\
\end{array}$ \\
\hline Home size & & & $\begin{array}{c}0.0055 \\
(0.0018)^{* *}\end{array}$ \\
\hline Home size/Total Family Size & & & $\begin{array}{c}-0.0142 \\
(0.0065) *\end{array}$ \\
\hline Age Head Started Work & & & $\begin{array}{c}0.0221 \\
(0.0087) *\end{array}$ \\
\hline Constant & $\begin{array}{c}0.7203 \\
(0.2590) * *\end{array}$ & $\begin{array}{c}6.8413 \\
(3.1151)^{*}\end{array}$ & $\begin{array}{c}5.1128 \\
(0.3863) * *\end{array}$ \\
\hline Mill's ratio & $\begin{array}{c}0.3204 \\
(0.1097)^{* *}\end{array}$ & $\begin{array}{c}2.6698 \\
(1.3331)^{*}\end{array}$ & \\
\hline Observations & 1426 & 1426 & 2411 \\
\hline
\end{tabular}

Table 3: SHIW Saving rate equations

In Table 3 we report estimation results. The first column presents estimates of the saving rate equation, the third column of the selectivity probability. Consistent standard errors are reported in parentheses.

The probability of observing at least one child living with the head decreases with the head's and spouse's age and with the number of pensioners, it increases with the total number of household members (whether present or not). Home size has a positive effect, as well as the age when the head started working. Per-capita home size (defined as the ratio of home squared 
meters to total household members) has a negative impact on this probability. Wealth and income variables are instead not significant.

The saving rate is negatively affected by beginning of period wealth, by the number of resident household members and by the student status dummy. Total personal income has a strong positive effect, and so does the total number of household members. The income share of the oldest child has a significant and positive effect on the saving rate: an $1 \%$ increase in this share boosts the saving rate by $.27 \%$.

This result is in line with the theoretical model presented above, as long as children who live with their parents intend to leave home eventually.

We also estimated a similar specification for a saving rate equation where saving is defined as the change in financial wealth between years 2000 and 2002. This is a noisy measure, and parameter estimates (reported in column 2 of Table 3) are imprecisely estimated. In particular, those coefficients that retain significance have the same signs as in column 1, but many parameter estimates are not significantly different from zero, including those on the two income variables. 


\begin{tabular}{|c|c|c|c|c|}
\hline & $\begin{array}{l}\text { Household } \\
\text { saving rate } \\
\text { exit=1 }\end{array}$ & $\begin{array}{l}\text { Household saving } \\
\text { rate exit=0 }\end{array}$ & $\begin{array}{l}\text { Child saving rate } \\
\text { exit=1 }\end{array}$ & $\begin{array}{l}\text { Child saving rate } \\
\text { exit }=0\end{array}$ \\
\hline \multicolumn{5}{|c|}{ Children variables (measured at time $t$} \\
\hline Age & $\begin{array}{l}0.4042 \\
(0.5797) \\
\end{array}$ & $\begin{array}{l}0.1010 \\
(0.1884) \\
\end{array}$ & $\begin{array}{l}0.0118 \\
(0.2203) \\
\end{array}$ & $\begin{array}{l}0.0483 \\
(0.0(149)\end{array}$ \\
\hline$\Lambda \mathrm{ge}^{2}$ & $\begin{array}{l}0.0857 \\
(0.1157)\end{array}$ & $\begin{array}{l}0.0298 \\
(0.0349)\end{array}$ & $\begin{array}{l}0.0065 \\
(0.0440)\end{array}$ & $\begin{array}{l}0.0160 \\
(0.0120)\end{array}$ \\
\hline Income share child & $\begin{array}{l}0.1501 \\
(0.1263) \\
\end{array}$ & $\begin{array}{l}-0.0163 \\
(0.0045) * *\end{array}$ & $\begin{array}{l}-0.0656 \\
(0.0479) \\
\end{array}$ & $\begin{array}{l}-0.0019 \\
(0.0016) \\
\end{array}$ \\
\hline Main activity $=$ study & $\begin{array}{l}-0.0486 \\
(0.0572) \\
\end{array}$ & $\begin{array}{l}-0.0162 \\
(0.0234) \\
\end{array}$ & $\begin{array}{l}-0.0227 \\
(0.0217) \\
\end{array}$ & $\begin{array}{l}-0.0113 \\
(0.0081) \\
\end{array}$ \\
\hline $\begin{array}{l}\text { Sutislaction wilh job security } \\
\text { Question not answered (not working) }\end{array}$ & $\begin{array}{l}-0.0326 \\
(0.057 .3) \\
\end{array}$ & $\begin{array}{l}0.0124 \\
(0.02 .32) \\
\end{array}$ & $\begin{array}{l}-0.0146 \\
(0.0278) \\
\end{array}$ & $\begin{array}{l}-0.0322 \\
(0.0080) * *\end{array}$ \\
\hline $\begin{array}{l}\text { Satislaction with job security } \\
\text { Very dissatisfied }\end{array}$ & $\begin{array}{l}-0.0869 \\
(0.1742) \\
\end{array}$ & $\begin{array}{l}0.0757 \\
(0.0511) \\
\end{array}$ & $\begin{array}{l}-0.0185 \\
(0.0661) \\
\end{array}$ & $\begin{array}{l}-0.0256 \\
(0.0176) \\
\end{array}$ \\
\hline $\begin{array}{l}\text { Satisfaction with job security } \\
\text { Dissatisfied }\end{array}$ & $\begin{array}{l}0.0016 \\
(0.1056) \\
\end{array}$ & $\begin{array}{l}-0.0677 \\
(0.0516) \\
\end{array}$ & $\begin{array}{l}-0.0063 \\
(0.0402) \\
\end{array}$ & $\begin{array}{l}-0.0374 \\
(0.0178) * \\
\end{array}$ \\
\hline $\begin{array}{l}\text { Satisfaction with job security } \\
\text { ^ bil dissatislied }\end{array}$ & $\begin{array}{l}-0.0029) \\
(0.0871)\end{array}$ & $\begin{array}{l}0.0170 \\
(0.0404)\end{array}$ & $\begin{array}{l}-0.0351 \\
(0.0332) \\
\end{array}$ & $\begin{array}{l}-0.0085 \\
(0.0139) \\
\end{array}$ \\
\hline $\begin{array}{l}\text { Satisfaction with job security } \\
\Lambda \text { bit satisfied }\end{array}$ & $\begin{array}{l}0.051 .3 \\
(0.0809) \\
\end{array}$ & $\begin{array}{l}0.001 .3 \\
(0.0326) \\
\end{array}$ & $\begin{array}{l}0.0282 \\
(0.0308) \\
\end{array}$ & $\begin{array}{l}-0.0240 \\
(0.0112)^{*}\end{array}$ \\
\hline \multicolumn{5}{|c|}{ Ilousehold (parent) variables (measured at time $t$ ) } \\
\hline Other head of houschold: yes & $\begin{array}{l}0.1787 \\
(0.2757) \\
\end{array}$ & $\begin{array}{l}0.0723 \\
(0.1310) \\
\end{array}$ & $\begin{array}{l}0.1056 \\
(0.1049) \\
\end{array}$ & $\begin{array}{l}0.0401 \\
(0.0452) \\
\end{array}$ \\
\hline Age household head & $\begin{array}{l}-0.0035 \\
(0.0048) \\
\end{array}$ & $\begin{array}{l}0.0001 \\
(0.0019) \\
\end{array}$ & $\begin{array}{l}-0.0014 \\
(0.0018) \\
\end{array}$ & $\begin{array}{l}-0.0002 \\
(0.0007) \\
\end{array}$ \\
\hline Age spouse & $\begin{array}{l}-0.0034 \\
(0.0052)\end{array}$ & $\begin{array}{l}0.0040 \\
(0.0021)\end{array}$ & $\begin{array}{l}0.0013 \\
(0.0020)\end{array}$ & $\begin{array}{l}0.0004 \\
(0.0007)\end{array}$ \\
\hline No spouse & $\begin{array}{l}0.1471 \\
(0.257 .3) \\
\end{array}$ & $\begin{array}{l}0.18 .5 .3 \\
(0.1022) \\
\end{array}$ & $\begin{array}{l}0.0 .574 \\
(0.0979) \\
\end{array}$ & $\begin{array}{l}0.0148 \\
(0.0 .352) \\
\end{array}$ \\
\hline Household income & $\begin{array}{l}4.8260 \\
(1.1007) \% \%\end{array}$ & $\begin{array}{l}1.9247 \\
(0.4619)^{26 \% 6}\end{array}$ & $\begin{array}{l}0.1796 \\
(0.4187) \\
\end{array}$ & $\begin{array}{l}-0.3129 \\
(0.1592)^{* 6}\end{array}$ \\
\hline IIII Financial wealth & $\begin{array}{l}-2.167 .3 \\
(0.4022) * *\end{array}$ & $\begin{array}{l}1.4179 \\
(0.1712) * *\end{array}$ & $\begin{array}{l}0.01 .31 \\
(0.15 .31)\end{array}$ & $\begin{array}{l}0.197 .3 \\
(0.0590) * *\end{array}$ \\
\hline Real wealth & $\begin{array}{l}0.3368 \\
(0.1891) \\
\end{array}$ & $\begin{array}{l}0.0492 \\
(0.0278) \\
\end{array}$ & $\begin{array}{l}0.0531 \\
(0.0719) \\
\end{array}$ & $\begin{array}{l}0.0009 \\
(0.0096)\end{array}$ \\
\hline Constant & 0.6342 & -0.1293 & -0.0646 & 0.0823 \\
\hline & $(0.7687)$ & $(0.2196)$ & $(0.2922)$ & $(0.0757)$ \\
\hline Mills ratio & -0.0287 & -0.0088 & 0.0310 & -0.0023 \\
\hline & $(0.0801)$ & $(0.082)$ & $(0.0 .30 .5)$ & $(0.0276)$ \\
\hline Observations & 439 & 2374 & 439 & 2374 \\
\hline p-val chi2-test satisfaction job security & 0.95 & 0.46 & 0.7 .3 & 0.00 \\
\hline p-val chi2-test age function & 0.74 & 0.11 & 0.37 & 0.00 \\
\hline
\end{tabular}

\section{Table 4: SEP Saving Rate Equations}

In Table 4 we report parameter estimates of four saving equations for the Dutch SEP data. The estimation sample is further reduced compared to Table 2 because observations presenting outliers in the dependent variables have been dropped. The results of the selection probability 
equation are omitted but are very similar to those reported in Table 2. ${ }^{6}$

The upper portion of Table 4 contains parameter estimates corresponding to child-level variables, the lower part to household or $\mathrm{HH}$ variables. The dependent variable in columns (1) and (2) is the change in household financial wealth between times $(t-1)$ and $t$ to household income over that year: column (1) is estimated over the sample of households where the child leaves at time $(t+1)$ - or "leavers" (439 observations in all) ; column (2) over the sample where the child stays with the parents at $(t+1)$ - or "stayers" (2374 observations). The dependent variable in columns (3) and (4) is the ratio of the change in child financial wealth between times $(t-1)$ and $t$ to household income over that year. Again, one column refers to leavers, the next to stayers. In the lower part of the Table we also report coefficients on the selectivity correction term (the Mill's ratio), the constant and the number of observations in each group (leavers and stayers).

The key explanatory variable is the child's "income" share. In the Dutch data, this is defined as the ratio of the child's cash in hand (income plus liquid assets minus debt) to household cash in hand. In fact, as noted in Section 4, SEP records individual wealth as well as income, and cash in hand is a better indicator of bargaining power than income. Cash in hand is positive for the vast majority of the children in our estimation sample (2914 out of 3044 - for comparison, child income is positive for 2616 observations). The child's share in cash in hand exceeds the $20 \%$ mark in 148 cases when the child is a student, and in 737 cases when the child is not (in our sample we have 1738 students, and 1306 not students).

Turning our attention to column (1) estimates (leavers), we notice that household income has a positive effect on the household saving rate, household financial wealth a negative effect. These are the only two coefficients that are significant at conventional levels. Household real wealth also has a positive coefficient, and so does the "income" (more precisely cash in hand) share of the child, but in both cases the t-statistic is little over unity. Column (2) estimates (stayers) of household income and financial wealth effects are similar (albeit smaller in absolute terms), while the child's "income" share is significantly negative. This result agrees well with the model predictions. In neither column are the job-security variables significant, suggesting that this particular motive for precautionary saving is of little consequence for total household saving.

The third column - child saving rate equation for leavers - has no significant coefficient, 
reflecting in part the small sample size and the greater variability in the dependent variable. Column (4) estimates - child saving rate for stayers - are more precise (the sample size is much larger). Significant coefficients are found on the variable indicating that the child is not working, two job security dummies and financial wealth. The coefficient on child's "income" share is negative but with an absolute t-ratio of just over unity. Perhaps the most interesting implication of this second set of estimates is that lack of job security plays a negative role on the child's saving rate: compared to the control group (very satisfied with job security) all stayers save less.

The empirical results presented in this Section can be summarized as follow:

1. In the Italian data, the child's income share has a strong, positive effect on household saving

2. In the Dutch data, the same variable has a negative effect on household saving if the child stays with the family at least one more year, it has a positive (but insignificant) effect if the child leaves next year.

These results can be reconciled with the theoretical model predictions if we take into account the institutional differences across the two countries' housing and credit markets (already discussed in Section 4). In Italy renting is not an option for most of the young, and there is a heavy transaction cost to be borne related to the purchase of housing stock (large down-payment requirements). In the Netherlands, cheap renting accommodation is available, and the young who can also borrow more liberally - typically rent for a few years and then buy their home. The relatively small transaction cost - particularly for would-be renters - may explain why leavers do not apparently use their income to save more (even though the point estimate is positive and its lack of precision is likely due to the small sample size). The negative effect of the child's income share for those who stay is also consistent with the notion that the transaction cost is relatively small: those children who do not leave immediately do not need to start saving up towards their move, and behave as if they intended to stay with their parents forever. 


\section{Conclusions}

In this paper we have addressed the issue of how the saving rate is affected by the decision of young adults to leave the parental home or to stay. This issue is of great relevance in some Southern European countries, where children stay with their parents well into their late twenties and early thirties, but is becoming more important in some Central-Northern European countries, albeit at younger ages (18-24). For this reason this paper uses micro data from a Southern European country, Italy, and from a Central-Northern country, the Netherlands.

We have developed a two-period game-theoretical model of the joint consumption - cohabitation decision, and found that the household saving rate should be affected by the child's income share. Such effect should be positive for children who intend to leave, negative for those who intend to stay in the parental home. Things that we have not considered in our theoretical model are uncertainty and multiple periods. Uncertainty in the unitary model implies less saving when there are more income earners if labor income risk is not fully insurable. This is not necessarily true in a collective model, as explained by Mazzocco [19] and is not borne out in estimation. Multiple periods would allow us to distinguish between late leavers and early leavers (at present, we only consider leavers and stayers). Finally, we have not considered here transfers from parents to children, or intra-family borrowing.

Empirical results from both countries are supportive of the key model predictions. We find strong positive effects of the child's income share on the saving rate in Italy, where we are able to calculate saving as the difference between disposable income and consumption but only use cross-sectional variability in estimation (and cannot therefore distinguish leavers from stayers). We also find some significant effects of the child's income share on household saving rate in the Netherlands, where saving is computed as the change over time in financial wealth. In the Dutch data we observe households over a long time period, and we can therefore distinguish between stayers and leavers. Interestingly, the effect of the child's income share is significantly negative for stayers, positive (albeit insignificant) for leavers.

The evidence is best explained if we take into account differences in housing and credit markets across the two countries, implying that transactions costs for children who leave the parental home are much more important in Italy than in the Netherlands. 


\section{References}

[1] Alessie, R. and A. Kapteyn, (2003) "Savings and pensions in the Netherlands", in Life cycle savings and public policy, Axel Boersch-Supan (Ed.) New York: Academic Press.

[2] Alessie, R., A. Lusardi, and T. Aldershof (1997), "Income and wealth over the Life Cycle: Evidence from panel data," Review of Income and Wealth, 43, 1-32.

[3] Attanasio, Orazio (1998), "A cohort analysis of saving behavior by US households," Journal of Human Resources, 33, 575-609.

[4] Barbagli Marzio; Maria Castiglioni and Gianpiero Dalla Zuanna (2003), Fare famiglia in Italia. Un secolo di cambiamenti, Bologna: Il Mulino.

[5] Battistin, Erich, Raffaele Miniaci and Guglielmo Weber (2003) "What do we learn from recall-consumption data?", Journal of Human Resources, 38(2), 354-385

[6] Becker, Sascha O., Samuel Bentolila, Ana Fernandes and Andrea Ichino (2002) "Job insecurity and children's emancipation: The Italian puzzle", unpublished manuscript

[7] Billari, Francesco C, Dimiter Philipov and Pau Baizán (2001) "Leaving home in Europe:the experience of cohorts born around 1960", Max Planck Institute for Demographic Research WP 2001-014

[8] Brandolini, Andrea and Luigi Cannari (1994), "Methodological appendix: the Bank of Italy's Survey of Household Income and Wealth," in Saving and the accumulation of wealth: essays on Italian households and government behavior, Albert Ando, Luigi Guiso and Ignazio Visco (Eds.). Cambridge: Cambridge University Press.

[9] Brugiavini, Agar and Mario Padula (2001) "Too much for retirement? Saving in Italy", Research in Economics, 55, 39-60

[10] Brugiavini, Agar and Guglielmo Weber (2003) "Household Saving: Concepts and Measurement", in Life cycle savings and public policy, Axel Boersch-Supan (Ed.) New York: Academic Press.

[11] Browning, Martin (2000) "The saving behavior of a two-person household", Scandinavian Journal of Economics, 102, 235-251 
[12] Chiuri, Maria Concetta and Tullio Jappelli (2003) "Financial market imperfections and home ownership: A comparative study", European Economic Review, 47, 857-875.

[13] Fernández Cordón, Juan Antonio (1997) "Youth residential independence and autonomy: a comparative study", Journal of Family Issues, 16(6): 567-607.

[14] Fogli, Alessandra (2000) "Endogenous labor market rigidities and family ties", unpublished manuscript

[15] Guiso, Luigi and Tullio Jappelli (2002) "Private transfers, borrowing constraints and the timing of home-ownership", Journal of Money, Credit and Banking, 34(2), 315-339

[16] Kiernan, Kathleen E. (1986) "Leaving Home: Living Arrangements of Young People in Six West-European Countries", European Journal of Population, 2: 177-184.

[17] Kiernan, Kathleen (1999) "Cohabitation in Western Europe", Population Trends, 26: 2532.

[18] Manacorda, Marco and Enrico Moretti (2003) "Why do most Italian youths live with their parents? Intergenerational transfers and household structure", unpublished manuscript

[19] Mazzocco, Maurizio (2003) "Saving, risk sharing and preferences for risk", unpublished manuscript

[20] Vermeulen, Frederic (2002) "Collective household models: Principles and main results", Journal of Economic Surveys, 16(4), 533-564 


\section{Endnotes}

1. We are grateful to Raffaele Miniaci for making this Figure available to us.

2. Barbagli et al. [4] also stress that in Italy leaving parental home late may be the best choice for children who value independence, but cannot afford to move out without incurring substantial costs.

3. Brugiavini and Weber [10] discuss some conceptual issues on the definition of saving; Battistin, Miniaci and Weber [5] investigate the properties of consumption data based on recall questions.

4. A respondent is a member of the household who is at least 16 years old.

5. The saving rate here is defined as $\frac{Y-C}{C}$ (where $Y$ is the sum of personal incomes of parents and child, and $C$ is non-durable consumption). Taking the ratio of saving to income creates problems with zero or negative income observations. The alternative definition we adopt is due to Attanasio [3]: it is a monotonic transformation of the standard definition when income is positive and consumption is a normal good.The saving rate here is defined as $\frac{Y-C}{C}$ (where $Y$ is total household income and $C$ is non-durable consumption). For consistency, we also take the ratio of the change in financial wealth over time to $C$.

6. We have assumed that the following variables only affect the exit probability and not the saving behaviour: dummies indicating the perception of the housing situation by the child, dummies indicating past changes in financial situation and the gender of the child (females are much more likely to leave earlier). 